\title{
Mistisisme dalam Program Televisi (Analisis Resepsi Pemirsa pada Program Menembus Mata Bathin di ANTV)
}

\author{
Muhamad Ridwan, Nawiroh Vera* \\ Universitas Budi Luhur \\ Jalan Raya Ciledug, Petukangan, Utara, Jakarta Selatan, Daerah Khusus Ibukota Jakarta \\ 12260 \\ *e-mail : nawiroh.vera@budiluhur.ac.id
}

\begin{abstract}
The purpose of this study was to determine the meaning of television viewers who are members of the ANTV's Facebook Fans Group about the element of mystical in the program of Menembus Mata Batin at ANTV Episode 15 December 2018. This research approach is qualitative using the Reception Analysis method. The theory used is David Morley's Reception Analysis Theory (Encoding-Decoding) which has three categories namely Dominant Position, Negotiated Position, and Oppositional position. Data collection techniques in this study used in-depth interviews with ten informants. The results showed that the informants interpreted the mystical message of the program differently from one another. This happens because the decoding produced by the informants varies according to socio-demographic factors (class, age, gender, religion, culture) as well as other factors such as the level of individual belief in the supernatural that they have. The conclusion of this study is ten informants and seven questions get thirtyfive meaning of Dominant Position, twenty-six interpretations of Negotiated Position and Nine Meanings of Oppositional position, so that in this study as a whole the most meaning is in the dominant meaning, which means the audience members meanings Facebook groups can interpret the contents of the mystical elements of the program Menembus Mata Batin according to what the text producer provided in the show.
\end{abstract}

Keywords: Reception Analysis, Messages, Mystical Elements, television programs

\section{ABSTRAK}

Penelitian ini bertujuan untuk mengetahui pemaknaan pemirsa televisi yang tergabung di dalam Fans Group facebook Menembus Mata Bathin ANTV terhadap pesan unsur mistik dalam program Menembus Mata Bathin di ANTV Episode 15 Desember 2018. Pendekatan penelitian ini adalah kualitatif dengan menggunakan metode Analisis Resepsi. Teori yang digunakan adalah Teori Analisis Resepsi David Morley (Encoding-Decoding) yang memiliki tiga kategori yaitu Dominant Position, Negotiated Position, dan Oppositional position. Teknik pengumpulan data menggunakan wawancara mendalam dengan sepuluh informan. Hasil penelitian menunjukan bahwa ditemukannya pemaknaan yang berbeda-beda dalam memaknai pesan unsur mistik pada program Menembus Mata Bathin di ANTV Episode 15 Desember 2018. Hal ini terjadi karena Decoding yang dihasilkan informan bervariasi menurut faktor sosio-demografis (kelas, usia, jenis kelamin, agama, budaya) serta faktor lain seperti tingkat keyakinan individual terhadap alam ghaib yang mereka miliki.Kesimpulan dari penelitian ini adalah sepuluh informan dan tujuh pertanyaan mendapatkan tiga puluh lima pemaknaan Dominant Position, dua puluh enam pemaknaan Negotiated Position dan Sembilan pemaknaan Oppositional position terhadap pesan unsur mistik dalam program Menembus Mata Bathin di ANTV Episode 15 Desember 2018, sehingga dalam penelitian ini secara keseluruhan pemaknaan yang paling banyak terdapat pada pemaknaan dominan yang artinya khalayak anggota fans group facebook dapat 
memaknai isi pesan unsur mistik pada program Menembus Mata Bathin Episode 15 Desember 2018 sesuai apa yang diberikan produsen teks dalam tayangan tersebut.

Kata kunci: Analisis Resepsi, Pesan, Unsur Mistik, program televisi 


\section{Pendahuluan}

Menembus Mata Bathin merupakan salah satu program reality show bertema mistik di stasiun televisi ANTV yang tayang setiap hari pada pukul 22.30 WIB sampai 01.30 WIB yang menghadirkan pria indigo Roy Kiyoshi sebagai pengisi acara utama, ditemani Sara Wijayanto, Bayu Oktara, dan Vicky Nitinegoro. Sejatinya program ini merupakan reinkarnasi dari tayangan Karma yang sebelumnya tayang di stasiun televisi ANTV. Program ini menyajikan hiburan, realita serta sisi lain kehidupan masyarakat yang masih percaya dengan hal-hal yang berhubungan dengan dunia tak kasat mata. Roy Kiyoshi didampingi oleh seorang pembawa acara yang membantu dua partisipan di setiap episodenya dalam mencari solusi dari permasalahan yang ia alami yang berhubungan dengan dunia lain. Pada tanggal 15 Desember 2018 program acara "Menembus Mata Bathin" Roy Kiyoshi yang berperan sebagai pria indigo membantu seorang partisipan pertama bernama samaran Ojan yang mengaku dirinya telah diberikan pegangan (jimat pengasihan) oleh seseorang yang berfungsi untuk mempermudah penghasilan, akan tetapi pegangan (jimat pengasihan) tersebut justru membuatnya lebih sulit untuk mendapatkan pekerjaan dan datang ke acara Menembus Mata Bathin untuk mencari solusi dari permasalahannya tersebut. Partisipan kedua bernama samaran Dina yang mengaku bahwa ayahnya menekuni dunia mistis dan mewarisi ilmu hitam tersebut kepada Dina dan dantang ke acara Menembus Mata Bathin untuk melepas keterikatan dengan dunia mistis tersebut.

Ketertarikan peneliti dalam mengambil episode pada Tanggal 15 Desember 2018 untuk diteliti karena dalam episode ini terbilang menarik, yaitu dimana cara-cara Roy Kiyoshi dalam membantu partisipan dengan kekuatan indera keenamnya seperti membaca masa depan atau masa lalu partisipan, menggambar sesosok makhluk halus menyeramkan di atas meja dan menaburkan suatu bubuk yang disebutnya bubuk suci kepada wajah partisipan untuk mengusir makhluk halus yang merasuki partisipan tersebut. Dalam episode ini juga menayangkan jimat pengasihan dan ritual seorang partisipan memakan hati hewan yang sudah busuk dan dibelatungi yang telah disensor serta kejadian-kejadian mistis seperti seorang kru ANTV yang memuntahkan belatung dan juga munculnya banyak belatung di tribun penonton secara tiba-tiba yang cukup menggiring perhatian pemirsa dan menghasilkan makna yang berbeda-beda sesuai dengan yang diamati.

Penelitian ini menggunakan analisis resepsi yang berfokus pada proses decoding oleh khalayak, sehingga dapat dilihat melalui persepsi, pemikiran, dan interpretasi. Lalu kemudian hasil yang didapatkan dikategorisasikan berdasarkan posisi khalayak pada tiga posisi hipotesis David Morley didalam pembaca teks (program acara) mengadopsi tiga kemungkinan yakni dominant position, negotiated position dan oppositional position.

Dalam penelitian ini peneliti memilih informan yaitu anggota Fans Group Menembus Mata Bathin ANTV |[MMB]| Facebook. Karena Fans Group tersebut sudah memiliki anggota sebanyak 264.882 dan aktif dalam menonton acara Menembus Mata Bathin serta memposting ratusan postingan dengan opini yang berbeda-beda setiap harinya berkaitan dengan acara Menembus Mata Bathin tersebut. Peneliti menyeleksi dan memilih sepuluh orang informan dengan latar belakang yang berbeda-beda untuk melakukan wawancara mendalam Oleh karena itu data dari observasi serta 
wawancara mendalam informan merupakan penonton yang aktif dan menyukai keseluruhan isi acara Menembus Mata Bathin di ANTV, ini merupakan masuk ke dalam kategori target penonton sebagai subjek penelitian.

Berdasarkan latar belakang penelitian, maka rumusan masalah dalam penelitian ini adalah Bagaimana penerimaan pemirsa televisi terhadap pesan unsur mistik dalam Program "Menembus Mata Batin" di ANTV? Tujuan penelitian ini dilakukan untuk mendeskripsikan penerimaan pemirsa televise berdasarkan tiga kategori di dalam analisis resepsi yaitu posisi dominan, posisi negosiasi, dan posisi oposisi.

\section{Kajian Pustaka}

a. Media Massa

Media massa merupakan sarana penyampaian komunikasi dan informasi yang melakukan penyebaran informasi secara missal dan dapat diakses oleh masyarakat secara luas pula. (Tamburaka, 2012:13). Media massa menyebarkan pesan-pesan yang mampu mempengaruhi khalayak, mencerminkan kebudayaan masyarakat, dan mampu menyediakan informasi secara simulta ke khalayak luas, anonim dan heterogen. Hal tersebut membuat media merupakan bagian dari kekuatan institusional dalam masyarakat. (Suryanto, 2015:147). "Media massa dalam kajian komunikasi massa sering dipahami sebagai perangkat yang diorganisasikan untuk berkomunikasi secara terbuka dan pada situasi yang berjarak pada khalayak luas dalam waktu yang singkat".

\section{b. Televisi Sebagai Media Massa}

Pengertian televisi adalah paduan radio (broadcast) dan film (moving picture). Televisi terdiri dari kata "tele" yang berarti jauh dan "vision". Dengan demikian television diartikan alat dengan melihat jauh. Melihat jauh disini diartikan dengan gambar dan suara yang diproduksi disuatu tempat (di studio televisi) dapat dilihat dari tempat lain melalui sebuah perangkat (televisi set). Segi positif televisi yakni langsung, tidak mengenal jarak, memiliki daya tarik yang kuat terdapat pula pada siaran televisi. (Effendy, 2003:274).

Terdapat tiga fungsi utama dari media televisi yaitu:

- Hiburan: fungsi hiburan untuk media elektronik ini menduduki posisi yang paling tinggi dibandingkan dengan fungsi-fungsi lain. Individu ataupun masyarakat menganggap bahwa media ini sebagai alat untuk pelepasan lelah

- Penyebaran informasi: mempelajari ancaman dan peluang, memahami lingkungan dan peristiwa, menguji kenyataan dan meraih keputusan

- Pendidikan: memperoleh pengetahuan dan keterampilan yang berguna memfungsikan dirinya secara efektif dalam masyarakatnya, mempelajari nilai, tingkah laku yang cocok agar diterima masyarakat. (Vera, 2016:78).

\section{c. Program Reality Show}

Reality show merupakan program yang mencoba menyajikan suatu keadaan yang nyata dengan cara sealamiah mungkin tanpa rekayasa, namun pada dasarnya reality show tetap merupakan permainan (game). (Morissan, 2005:106). Adapun bentuk-bentuk reality show, yaitu:

- Hidden Camera atau kamera tersembunyi. Ini merupakan program yang paling realistis yang menunjukan situasi yang dihadapi seseorang secara apa adanya. Kamera ditempatkan secara tersembunyi yang mengamati gerak-gerik atau tingkah laku subjek yang berada di tengah situasi yang 
sudah dipersiapkan sebelumnya (direkayasa).

- Competition Show. Program ini melibatkan beberapa orang yang saling bersaing dalam kompetisi yang berlangsung selama beberapa hari atau minggu untuk memenangkan perlombaan, permainan (game), atau pertanyaan. Setiap peserta akan tersingkir satu persatu melalui pemungutan suara (voting), baik oleh peserta sendiri ataupun audien. Pemenangnya adalah peserta paling akhir bertahan.

- Relationship show. Seorang kontestan harus memilih satu orang dari sejumlah orang yang berminat untuk menjadi pasangannya. Para peminat harus bersaing untuk merebut perhatian kontestan agar tidak tersingkir dari permainan. Pada setiap episode ada satu peminat yang harus disingkirkan.

- Fly on the wall. Program yang memperlihatkan kehidupan sehari-hari dari seseorang (biasanya orang terkenal) mulai dari kegiatan pribadi sehingga aktivitas profesionalnya. Dalam hal ini, kamera membuntuti kemana saja orang bersangkutan pergi.

- Mistik. Program yang terkait dengan hal-hal supernatural menyajikan tayangan yang terkait dengan dunia ghaib, paranormal, klenik, praktik spiritual magis, mistik, kontak dengan roh, dan lain-lain. (Morissan, 2008:228)

\section{d. Khalayak Dalam Media Massa}

Dalam media massa, khalayak adalah masyarakat yang menggunakan media massa sebagai sumber pemenuhan kebutuhan bermedianya (Ardianto, Elvinaro, dkk, 2009:167).

\section{e. Khalayak Aktif Dan Khalayak Pasif}

Dalam teori komunikasi massa khalayak pasif dipengaruhi oleh media, sedangkan khalayak aktif menyatakan bahwa khalayak memiliki keputusan aktif tentang cara menggunakan media. (Suryanto, 2015:295)

Beberapa tipologi khalayak aktif yaitu:

- Selektivitas (selectivity). Khalayak aktif dianggap selektif dalam proses konsumsi media yang mereka pilih untuk digunakan. Mereka tidak asalasalan dalam memilih media, tetapi didasari alasan dan tujuan tertentu. Misalnya, kalangan bisnis lebih berorientasi pada majalah Swasembada dan Harian Bisnis Indonesia untuk mengetahui perkembangan dunia bisnis, penggemar olahraga memilih tabloid bola untuk mengetahui hasil berbagai pertandingan olahraga dan sebagainya.

- Utilitarianisme (utilitarianisme), Yaitu khalayak aktif memilih media untuk memenuhi kebutuhan dan tujuan tertentu yang mereka miliki.

- Intensionalitas (intentionality), yang mengandung makna penggunaan secara sengaja dari isi media.

- Keikutsertaan (involvement) Merupakan usaha. Maksudnya khalayak secara aktif berpikir mengenai alasan mereka dalam mengonsumsi media.

- Khalayak aktif dipercaya sebagai komunitas yang tahan dalam menghadapi pengaruh media (impervious to influence) atau tidak mudah dibujuk oleh media itu sendiri. (Suryanto, 2015:296)

\section{f. Pemaknaan}

Menurut Saussure makna diproduksi melalui proses seleksi dan kombinasi tanda-tanda di sekitar dua poros, yaitu 
poros sintagmatis (linear-misalnya kalimat) dan poros paradigmatic (arena tanda-misalnya sinonim), yang ditata di dalam sistem penandaan. Tanda yang terdiri dari penanda (media) dan nyata, namun ia membentuk makna dengan mengacu satu sama lain. Makna adalah konvensi sosial yang diorganisasi melalui relasi antartanda. (Barker, 2008:18)

Pemaknaan juga bisa terjadi pada khalayak yang mengkonsumsi media televisi. Proses ini terjadi akibat televisi memberikan makna-makna tekstual yang akan diterima oleh penonton dan kemudian penonton akan memahaminya berdasarkan kompetensi kultural masingmasing. Di dalam tradisi cultural studies menjelaskan bagaimana sebuah terjadinya pemaknaan dalam televisi. (Barker, 2008:286).

\section{g. Analisis Resepsi}

Analisis resepsi atau analisis penerimaan adalah teori berbasis khalayak yang berfokus pada bagaimana beragam jenis anggota khalayak memaknai bentuk konten tertentu. (Baran dan Davis, 2010:302)

Studi resepsi menyatakan bahwa apapun yang dilakukan analisis makna tekstual sebagai kritik masih jauh dari kepastian tentang makna yang teridentifikasi yang akan diaktifkan oleh pembaca/audien/konsumen. Yang dimaksudkan adalah bahwa audien merupakan pencipta aktif makna dalam kaitannya dengan teks. Dimana sebelumnya mereka membawa kompetensi kultural yang telah mereka dapatkan untuk dikemukakan dalam teks sehingga audien yang terbentuk dengan cara yang berbeda akan mengerjakan makna yang berlainan. (Barker, 2008:34)

Menurut ahli sosiologi Pertti Alasuutari berpendapat bahwa dalam perkembangannya, penelitian penerimaan (reception analysis) telah memasuki tahapan ketiga yakni:

- Tahap pertama berkutat pada pendekatan dalam pengodean penafsiran milik Stuart hall.

- Tahap kedua didominasi oleh studi etnografi yang dipelopori oleh David Morley.

- Dalam Tahap ketiga yang memunculkan sebuah kerangka luas yang mana orang yang membentuk media dan penggunaan media. Seseorang tidak perlu mengabaikan studi kasus etnografis terhadap khalayak atau analisis program individu, tetapi fokus utamanya tidak terbatas hanya mencari tahu mengenai penerimaan atau pemaknaan dari sebuah program oleh khalayak tertentu. Akan tetapi, tujuannya adalah untuk memahami "budaya media" kontemporer. (Baran dan Davis, 2010:305)

\section{h. Teori Encoding-Decoding}

Didalam analisis resepsi terdapat model encoding-decoding, Hall (1981) mengartikan proses encoding televisi sebagai artikulasi momen-momen produksi, sirkulasi, distribusi dan reproduksi, yang saling terhubung namun berbeda. Secara khusus, produksi makna tidak memastikan adanya konsumsi makna itu sebagaimana yang dikehendaki oleh pengode karena pesan-pesan televisi, yang dikonstruksi sebagai sistem tanda dengan komponen penekanan yang beraneka ragam, bersifat polesmik. Singkatnya, pesan-pesan televisi memikul berbagai makna dan dapat diinterpretasikan dengan cara yang berbeda. (Barker, 2008:297)

David Morley kemudian dalam buku Television, Audience \& Culture 2005 Mengikuti pemikiran Parkin menjelaskan 3 
kategoriasasi dari pemaknaan pembacaan khalayak terhadap teks media yaitu :

- Dominant Position, yaitu khalayak TV mengambil makna yang mengandung arti dari program TV dan meng-decode nya sesuai dengan makna yang dimaksud (preferred reading) yang ditawarkan teks media. Khalayak sudah punya pemahaman yang sama, tidak aka $\mathrm{n}$ ada pengulangan pesan, pandangan komunikator dan komunikan sama, langsung menerima.

- NegotiatedPosition, yaitu mayoritas khalayak memahami hampir semua apa yang telah didefinisikan dan ditandakan dalam program TV. Khalayak bisa menolak bagian yang dikemukakan, dipihak lain akan menerima bagian yang lain.

- Oppositional Position, yaitu khalayak membaca kode atau pesan yang lebih disukai dan membentuknya kembali dengan kode alternatif. Dalam bentuk ekstrem mempunyai pandangan yang berbeda, langsung menolak karena pandangan yang berbeda. (Morley: 2005:82)

\section{i. Mistik Dan Mistisme}

Istilah mistik berasal dari bahasa yunani 'mio' yang berarti menyembunyikan dan menutup mata atau mulut. Istilah mistik menurut teologi Kristiani disebut 'Gnosis' yaitu tingkat kemanunggalan (pengenalan Tuhan tanpa melalui persepsi dan rasio).Bagi golongan mistik Islam, istilah yang dipakai adalah makrifat. Tujuan pokok dari intisari mistik menurut Sri Mulyono yaitu berada dalam hadirat Ilahi dan memperoleh hubungan langsung yang disadari dengan Tuhan.Intinya ada kesadaran akan komunikasi antara roh manusia dengan Tuhan. (Musman, 2018:21)

Sedangkan Mistik sebagai sebuah paham disebut mistisme, sebagai paham yang memberikan ajaran bersifat serbamistis, ajarannya berbentuk rahasia atau serba rahasia, tersembunyi, gelap, atau terselubung dalam kekelaman, sehingga dapat dikenal, diketahui, atau dipahami oleh orang-orang tertentu saja, terutama sekali oleh para penganutpenganutnya. (Petir, 2014:15)

\section{j. Unsur Mistik}

Unsur mistik terbagi menjadi beberapa dimensi, antara lain:

- Ritualistik: dinamisme yaitu ritual pemujaan pada benda-benda atau kekuatan alam, seperti akik, keris, batu besar, makam-makam, benda ritual ghaib, dan lain-lain; animisme yaitu ritual pemujaan pada makhluk berkekuatan ghaib, meminta perlindungan, rejeki, dan lain-lain.

- Interaksi: persekutuan yaitu meminta tolong atau mencari solusi masalah pada makhluk atau kekuatan ghaib, meminta perlindungan, rezeki dan lain-lain; permusuhan yaitu bertarung dengan kekuatan ghaib, pertarungan antar makhluk ghaib.

- Visualisasi: penampakan realaitas ghaib, munculnya simbol, firasat/pertanda, makhluk ghaib, kekuatan supernatural, dan lain-lain.

- Karakter: karakter yang terlibat dalam peristiwa bermuatan mistik atau supernatural seperti kyai atau pemuka agama, dukun, manusia (laki-laki atau perempuan), makhluk atau kekuatan ghaib. (Anggraini, Jurnal E-Komunikasi, Januari 2013:5).

\section{Metode Penelitian}

Dalam penelitian ini peneliti menggunakan pendekatan kualitatif bertujuan untuk menggambarkan hasil penelitian dengan kata-kata tertulis dan bukan angka-angka secara pasti. Pemahaman tersebut tidak ditentukan 
terlebih dahulu tetapi diperoleh setelah melakukan analisis terhadap khalayak dalam menangkap sebuah isi pesan yang dimaknainya berbeda-beda sesuai sudut pandang mereka masing-masing dari media yang menjadi fokus penelitian. Kemudian ditarik kesimpulan beberapa pemahaman umum tentang kenyataankenyataan tersebut.

Metode penelitian yang digunakan peneliti adalah analisis resepsi, yaitu penelitian yang mendasar pada kesadaran atau cara subyek dalam memahami objek dan peristiwa dengan pengalaman individu. Analisis resepsi dapat melihat mengapa khalayak memaknai sesuatu secara berbeda, faktor-faktor psikologis dan sosial apa yang mempengaruhi perbedaan tersebut, dan apa konsekuensi yang muncul (Moleong, 2004:212). Tujuan peneliti menggunakan metode analisis resepsi karena peneliti ingin mengetahui bagaimana para informan menerima, memaknai, serta merespon pesan unsur mistik yang ditampilkan dalam tayangan Menembus Mata Batin di ANTV Episode 15 Desember 2018 yang diperoleh peneliti dari hasil wawancara.

\section{a. Subjek/objek Penelitian}

Objek Penelitian ini adalah program reality show Menembus Mata Batin di ANTV Episode 15 Desember 2018.

Subjek penelitian merupakan individu, benda atau organisme yang dijadikan sumber informasi yang dibutuhkan dalam pengumpulan data penelitian. Biasanya lebih dikenal dengan sebutan responden atau informan. Informan adalah orang yang dimanfaatkan untuk member informasi tentang situasi dan kondisi latar penelitian. (Moleong, 2013:132). Peneliti menggunakan subjek penelitian kepada sepuluh Anggota Fans Group Menembus Mata Bathin ANTV |[MMB]| Facebook dengan berbagai sosio-demografis (pekerjaan, usia, jenis kelamin, budaya, agama) yang berbeda-beda.

\section{b. Profil Informan}

Pada penelitian ini menentukan 10 (sepuluh) orang informan dari Anggota Fans Group Menembus Mata Bathin ANTV |[MMB]| Facebook dengan latar belakang yang berbeda-beda dan memenuhi kriteria untuk dijadikan sebagai seorang informan. Para informan tersebut kemudian akan peneliti mintai untuk menyaksikan kembali tayangan Menembus Mata Bathin ANTV pada episode 15 Desember 2018 tersebutpada lokasi tempat dan waktu yang terpisah. Hasil data yang didapat dari wawancara mendalam pada 10 (sepuluh) narasumber tersebut akan peneliti olah dan nantinya akan diambil kesimpulannya tentang bagaimana pemaknaan mereka terhadap pesan unsur mistik pada tayangan tersebut. Adapun ke 10 (sepuluh) orang informan tersebut sebagai berikut:

\section{c. Teknik Pengumpulan Data}

Data primer yang dilakukan peneliti adalah melakukan wawancara mendalam. Sedangkan Proses pengumpulan data sekunder, peneliti lakukan dengan cara mencari berbagai referensi dari berbagai buku, literature. Peneliti juga melakukan pencarian data-data tambahan melalui internet (website) sebagai bahan pertimbangan lain dalam menunjang penelitian ini.

\section{Hasil Pembahasan}

Hasil penelitian yang peneliti dapatkan ini merupakan hasil yang diperoleh dari wawancara mendalam setelah mempertontonkan program Menembus Mata Bathin episode 15 Desember 2018 yang sudah peneliti siapkan demi berlangsungnya penelitian ini.

Hasil penelitian ini menunjukan bahwa terdapat 35 posisi Dominant yang merupakan jumlah paling banyak 
dibandingkan dengan posisi Negotiated yang berjumlah 26 pemaknaan, dan posisi Oppositional dengan jumlah 9 pemaknaan. Yang terangkum di dalam tabel 1.

Tabel 1 menggambarkan hasil penelitian ini dengan rumusan masalah "Bagaimana penerimaan pemirsa televise terhadap pesan unsur mistik dalam Program "Menembus Mata Batin" Episode 15 Desember 2018 di ANTV?" dengan menggunakan analisis resepsi David Morley dimana khalayak menjadi audience yang aktif dalam memaknai isi teks media dimana decodingbervariasi menurut faktor sosio-demografis (kelas, usia, jenis kelamin, budaya) serta keyakinan masingmasing individu terhadap hal-hal mistis dan ghaib.

Tabel 1 Jumlah pemaknaan informan

\begin{tabular}{|c|c|c|c|c|c|c|c|c|c|c|}
\hline & $\begin{array}{c}\text { Inf } \\
1\end{array}$ & $\begin{array}{l}\ln \\
f_{2}\end{array}$ & $\begin{array}{l}\text { In } \\
f_{3}\end{array}$ & $\begin{array}{l}\text { In } \\
f_{4}\end{array}$ & $\begin{array}{l}\text { In } \\
f_{5}\end{array}$ & $\begin{array}{c}\text { Inf } \\
6\end{array}$ & $\begin{array}{l}\text { In } \\
f_{7}\end{array}$ & $\begin{array}{l}\text { In } \\
\text { f } 8\end{array}$ & $\begin{array}{l}\text { In } \\
f_{g}\end{array}$ & $\begin{array}{l}\operatorname{Inf} \\
10\end{array}$ \\
\hline 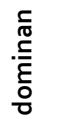 & 5 & 5 & 4 & 5 & 1 & 5 & - & 1 & 5 & 4 \\
\hline 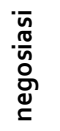 & 2 & 2 & 3 & 2 & - & 2 & 7 & 6 & 1 & 1 \\
\hline $\begin{array}{l}\overline{\bar{y}} \\
\bar{y} \\
0 \\
0\end{array}$ & - & - & - & - & 6 & - & - & - & 1 & 2 \\
\hline \multicolumn{11}{|c|}{ dominan = 35} \\
\hline \multicolumn{11}{|c|}{ negosiasi $=26$} \\
\hline \multicolumn{11}{|c|}{ opsisi = 9} \\
\hline & & & & jun & lah $=$ & & & & & \\
\hline
\end{tabular}

Dalam hal ini setelah menyaksikan program Menembus Mata Bathin episode 15 Desember 2018 di ANTVinformandarikalangan ibu rumah tangga, karyawan swasta dan seorang buruh yang berasal dari informan1,2,4,6,9 dan 10 setuju dan sejalan dengan keyakinan ansumsi makna dari tayangan tersebut yang menayangkan kemampuan indigo dari Roy Kiyoshi. Keenaminforman tersebut memiliki pemaknaan dominan yang sama yaitu memaknai kemampuan indigo dari Roy Kiyoshi berada di luar nalar manusia, dimana Roy Kiyoshi mampu untuk melihat makhluk halus serta dapat melihat masa lalu dan masa depan dari seseorang.

Selanjutnya pemaknaan dominan yang dihasilkan dari pemaknaan pelaku mistis Ojan dari program Menembus Mata Bathin episode 15 Desember 2018 kembali dihasilkan dari kalangan ibu rumah tangga, karyawan swasta dan seorang buruh yang berasal dari informan1,2,3,4,6,8,9 dan 1oyang memahaminya dengan sangat baik isi pesan dari tayangan tersebut yang menceritakan pengakuan masa lalu kelam dari seseorang pengguna jimat pengasihan bernama Ojan. Pada pelaku mistis Dina juga mereka sama halnya memiliki pemahaman yang sama dengan apa yang dimaksud oleh program tersebut dengan baik dan dapat memahami isi pesan dari tayangan tersebut yang menceritakan seorang yang bernama Dina yang merupakan korban dari praktik ilmu hitam dari almarhum ayahnya.

Dalam tayangan program Menembus Mata Bathin episode 15 Desember 2018 di ANTV menayangkan ritual pemanggilan makhluk halus oleh Dina dengan cara membakar kemenyan dan memakan hati busuk yang kemudian menghasilkan pemaknaan dominan dari informan 1,2,4,6,9 dan 10 dari kalangan ibu rumah tangga, karyawan swasta dan seorang buruh dimana mereka setuju dan sependapat bahwaritual Dina tersebut merupakan cara dia untuk memanggil dan berkomunikasi dengan makhluk halus yang ditanamkan oleh ayahmya. Akan tetapi dari banyaknya informan, hanya informan 3,6 dan 9 yang setuju terhadap benda-benda mistis dalam tayangan ini seperti jimat pengasihan milik Ojan yang dipercaya memiliki kekuatan magis yang 
membuat pemiliknya mendapatkan kepercayaan orang lain dan boneka milik Frisly yang dipercaya memiliki kekuatan mistis untuk mengetahui keberadaan dari makhluk halus. Selanjutnya pemaknaan dominan yang dihasilkan dari acara tersebut mengenai adakah pesan moral dalam tayangan tersebutmenurut informan 1,2,3 yang berasal dari kalangan ibu rumah tangga dan informan 4 dari kalangan karyawan swasta memaknai pesan moral dalam tayangan ini bahwa pelaku mistis atau ilmu hitam dapat disembuhkan dan terlepas dari ilmu hitam tersebut selama mereka memiliki niat dan mau keluar dari ilmu hitam yang selama ini dijalani.

Hasil dari penelitian yang telah peneliti lakukan menunjukan bahwa:

a. Pemaknaan posisi dominan didominasi oleh kalangan ibu rumah tangga, karyawan swasta dan seorang buruh. Dimana mereka dapat memaknai isi pesan unsur mistik pada program Menembus Mata Bathin Episode 15 Desember 2018 dengan baik sesuai apa yang diberikan produsen teks dalam tayangan tersebut. Peneliti berpendapat bahwa pada dasarnya mereka memiliki rasa keingintahuan yang tinggi terhadap hal-hal mistis dan menyukai pembongkaran aib serta cerita masa lalu yang kelam dari para pelaku mistis yang membuat mereka menyukai program tersebut dan menyimak dengan baik seluruh isi acara yang pada akhirmya mereka menerima semua pesan unsur mistik yang disodorkan dan dikehendaki oleh pembuat program.

b. Pemaknaan posisi negosiasi di dominasi dari seorang guru mengaji dan seorang pedagang yang memiliki kepercayaan mistik kejawen. Dimana mereka menyesuaikan pandanganpandangan mereka didalam memaknai para pelaku mistis dalam tayangan ini sesuai dengan keyakinan agama maupun budaya mereka.

Kemudian pemaknaan oposisi di dominasi oleh seorang pemuda yang menolak hampir dari seluruh pesan unsur mistik pada tayangan tersebut. Menurut peneliti informan ini memiliki budaya dan pola pikir yang modern dan secara individual tidak mempercayai hal-hal mistis yang sudah ketinggalan zaman.

\section{Kesimpulan}

Dari penelitian yang telah peneliti lakukan, dapat disimpulkan bahwa secara keseluruhan pemaknaan yang paling banyak terdapat pada pemaknaan dominan yang artinya khalayak anggota fans group Menembus Mata Bathin ANTV |[MMB]| Facebook dapat memaknai isi pesan unsur mistik pada program Menembus Mata Bathin Episode 15 Desember 2018 sesuai apa yang diberikan produsen teks dalam tayangan tersebut. Namun kendati demikian ada beberapa informan yang menolak maupun memiliki pandangan yang berbeda, mereka membuat beberapa pengecualian atau menyesuaikan isi pesan unsur mistik tersebut kedalam keyakinan etnisitas budaya, agama dan faktor lain seperti tingkat keyakinan individual terhadap alam ghaib yang mereka miliki sehingga menghasilkan pemaknaan negosiasi dan oposisi.

Peneliti berharap khalayak bisa dengan bijak dalam menyikapi program Menembus Mata Bathin karena program tersebut bisa berdampak negatif maupun positif semua tergantung dari khalayak yang menyikapinya. Dan untuk instansi terkait tentang tayangan yang di rekayasa untuk memberikan penjelasan yang pasti terkait acara tersebut merupakan acara murni reality show atau hanya berisi kebohongan berkedok reality show. 


\section{Referensi}

Abimanyu, Petir. 2014. Ajaran-Ajaran Emas Ramayan: Mahabharata. Jakarta Selatan: Suka Buku.

Afdjani, Hadiono. 2015. Ilmu Komunikasi, Proses Dan Strategi. Tangerang. Indigo Media.

Ardianto, Elvinaro, dkk. 2009. Komunikasi Massa: Suatu Pengantar Edisi Revisi. Bandung: Simbiosa Rekatama Media.

Baran, Stanley J. dan Dennis K. Davis. 2010. Teori Komunikasi Massa: Dasar, Pergolakan, Dan Masa Depan. Jakarta. SalembaHumanika.

Barker, Crhist. 2008.Cultural Studies: Teori dan praktik. . Yogyakarta. Kreasi Wacana.

Effendy, Onong Uchana. 2003. Ilmu, teori dan filsafat komunikasi. Bandung. Citra Aditya Bakti.

Gunawan, Imam. 2017. Metodologi Penelitian Kualitatif: Teori dan praktik. Jakarta. PT. Bumi Aksara.

Irene Anggraini. Januari, 2013. "Sikap masyarakat Surabaya terhadap pesan mistik dalam program Acara Dua Dunia di Trans 7". Jurnal EKomunikasi, Vol1:1, diakses dari website https://media.neliti.com/media/publ ications/78385-ID-none.pdf ， pada tanggal 13 Januari 2019 pukul 17.13. WIB.

Morissan. 2005. Media Penyiaran Strategi Mengelola Radio dan Televisi. Tangerang. Penerbit Ramdina Perkasa.

Morissan. 2008. Manajemen Media Penyiaran: StrategiMengelola Radio \& Televisi. Jakarta, Kencana.
Musman, Asti. 2018. Bahagia Ala Orang Jawa. Yogyakarta. Pustaka Jawi.

Moleong, Lexy.J. 2004. Metodelogi Penelitian Kualitatif. Bandung. PT. Remaja Rosdakarya.

Moleong, Lexy.J. 2013 Metode Penelitian Kualitatif Edisi Revisi. Bandung. PT. Remaja Rosdakarya.

Morley, David. 2005. Television, Audience, \& Cultural Studies. London. Routledge.

Suryanto. 2015. Pengantar Ilmu Komunikasi. Bandung. Cv PustakaSetia.

Tamburaka, Apriadi. 2012. Agenda Setting Media Massa, Jakarta, Rajawali Pers.

Vera, Nawiroh. 2010. Pengantar Komunikasi Massa. Jakarta. Renata Pratama Media. 